\title{
OBEZITATEA LA PREŞCOLAR - STUDIU CAZUISTIC
}

\author{
Oana Teslariu', Carmen Oltean², Laura Alexandra Gavriluță ${ }^{3}$, \\ Maria Liliana Iliescu ${ }^{4}$, Dana-Teodora Anton-Păduraru ${ }^{1}$ \\ ${ }^{I}$ Clinica III Pediatrie, Universitatea de Medicină şi Farmacie ,, Gr. T. Popa “, Iaşi \\ ${ }^{2}$ Spitalul de Urgențe pentru Copii ,,Sf. Maria “, Iaşi \\ ${ }^{3}$ Universitatea de Medicină şi Farmacie ,, Gr. T. Popa“, Iaşi \\ ${ }^{4}$ Sănătate Publică şi Management Sanitar, \\ Universitatea de Medicină şi Farmacie „, Gr. T. Popa “, Iaşi
}

\begin{abstract}
REZUMAT
Obezitatea primară la copii, una dintre cele mai frecvente boli de nutriție din lume, prezintă particularități dependente de vârstă privind factorii de risc, măsurile de prevenție şi tratament. Obiectivul prezentului studiu a fost reprezentat de evaluarea pacienților de vârstă preşcolară diagnosticați cu obezitate primară în Clinica III Pediatrie a Spitalului de Urgență pentru Copii „Sf. Maria“ Iaşi în vederea identificării debutului supraponderalității/ obezității şi a factorilor de risc prenatali, postnatali precoce, acumulați în primii 6 ani de viață implicați în producerea obezității. Concluzionăm că accentul în combaterea obezității copilului trebuie pus pe profilaxia acesteia, deosebit de importante fiind măsurile pentru promovarea unei alimentații sănătoase şi pentru combaterea sedentarismului.
\end{abstract}

Cuvinte cheie: obezitate, preşcolar, exces caloric, sedentarism

\section{INTRODUCERE}

În ultimele decade, obezitatea - afecțiune complexă, multifactorială, a devenit una dintre cele mai frecvente boli de nutriție din lume, având amploarea unei pandemii, ceea ce a determinat Organizația Mondială a Sănătății (OMS) să o considere „boala secolului XXI“. Conform unui studiu efectuat în 79 de țări, OMS apreciază că există 250 de milioane de obezi în lume, dintre care 22 de milioane sunt copii cu vârstă mai mică de 5 ani $(1,2)$.

Obezitatea în rândul copiilor de vârstă preşcolară reprezintă o serioasă problemă de sănătate publică pretutindeni în lume, mai ales datorită consecinţelor pe care le poate avea asupra sănătății pe termen lung. Studii recente au demonstrat că, în cele mai multe cazuri, obezitatea cu debut în prima copilărie poate evolua şi la vârsta adultă, crescând astfel riscul apariției unor boli cu impact precoce asupra calității şi duratei vieții cum ar fi bolile cardiovasculare, diabetul zaharat de tip 2, complicaţii ortopedice, patologie psiho-comportamentală (3). De asemenea, riscul copiilor cu obezitate în primii ani de viață de a deveni adulți obezi este de $80 \%$ pentru cei cu ambii părinţi obezi şi de $40 \%$ pentru copiii cu un singur părinte obez.

Consecinţele fizice şi psihologice, costurile enorme asociate şi dificultăţile întâmpinate în cursul tratamentului obezităţii indică în mod clar necesitatea prevenției ca țintă de sănătate publică $(4,5)$. Identificarea factorilor de risc este un element cheie în reducerea incidenţei obezității în perioada copilăriei (6). Dovezile arată că o combinație cuprinzând intervenții asupra dietei, terapie comportamentală şi exerciții fizice are un impact semnificativ în reducerea greutății corporale a copiilor supraponderali şi obezi $(7,8)$.

Obiectivul prezentului studiu a fost reprezentat de evaluarea pacienţilor de vârstă preşcolară diagnosticați cu obezitate primară în Clinica III Pediatrie a Spitalului de Urgență pentru copii „Sf. Maria“ Iaşi, în vederea identificării debutului supraponderalității/obezității şi a factorilor de risc prenatali, postnatali precoce, acumulaţi în primii 6 ani de viață implicați în producerea obezității. 


\section{MATERIAL ŞI METODĂ}

A fost efectuat un studiu retrospectiv, pe o perioadă de 3 ani (2012-2014), pe un lot de 33 de pacienți de vârstă preşcolară (3-6 ani) diagnosticați cu obezitate primară în Clinica III Pediatrie din cadrul Spitalului Clinic de Urgență pentru Copii „Sf. Maria“ din Iaşi. Protocolul de studiu a cuprins:

Criteriile de includere în studiu: indice de masă corporală (IMC) peste percentila 95, excluderea obezității aparţinând unui sindrom genetic, endocrinopatii sau patologii psiho-somatice.

Anamneza generală: vârsta, sexul, mediul de proveniență (urban/rural), greutatea la naştere, alimentația şi ritmul de creştere în primul an de viață, vârsta la debutul creşterii ponderale excesive, circumstanțe precipitante, prezența unor boli cronice sau altor afecțiuni severe anterioare.

Anamneza familială: prezența obezității sau a altor afecțiuni induse sau agravate de obezitate (HTA, boli cardiovasculare, diabet zaharat, boli endocrine), concepția mamei în legătură cu: alimentația, ceea ce înseamnă un copil sănătos, cantitățile de alimente pe care trebuie să le primească copilul, obiceiurile alimentare.

Istoricul obezităţii: debutul şi circumstanțele aparente de declanşare, explorări şi atitudinea terapeutică anterioară, rezultatele încercărilor terapeutice anterioare şi motivul aparent al eşecului.

Ancheta alimentară: aprecierea ingestiei alimentelor din grupurile majore şi a frecvenței ingestiei alimentelor din fiecare grup pe baza declarațiilor făcute de mamă, prezența excesului de glucide, variațiile calorice de la o zi la alta, repartiţia caloriilor pe mese, aprecierea aportului caloric şi proteic al dietei comparativ cu recomandările uzuale.

Ancheta activității fizice: numărul de ore de somn, distanța de la domiciliu până la grădiniță, numărul de ore de activitate liberă (joc, plimbare), numărul de ore petrecute zilnic la televizor şi calculator, practicarea în familie de activități fizice.

Examenul clinic general al pacienților a fost completat cu măsurarea parametrilor antropometrici (greutate corporală, înălţime, indice de masă corporală).

\section{REZULTATE}

Cei 33 bolnavi cu obezitate primară au reprezentat $1,46 \%$ din totalul copiilor de aceeaşi vârstă spitalizați în perioada studiată. Analizând repartiția pe sexe, rezultatele studiului au confirmat datele din literatura de specialitate, sexul feminin predominând (sex ratio feminin: masculin=1,38:1).
Majoritatea pacienților investigați (64\%) locuiau în mediul urban, unde consumul de băuturi şi alimente hipercalorice, dar cu valoare nutrițională redusă, este mai crescut.

Rezultatele măsurătorilor parametrilor antropometrici au condus la încadrarea celor 33 de cazuri în diferite grade de obezitate (Fig. 1):

- obezitate gradul I (uşoară): 17 cazuri (52\%);

- obezitate gradul II (medie): 9 cazuri (27\%);

- obezitate gradul III (severă): 7 cazuri (21\%).

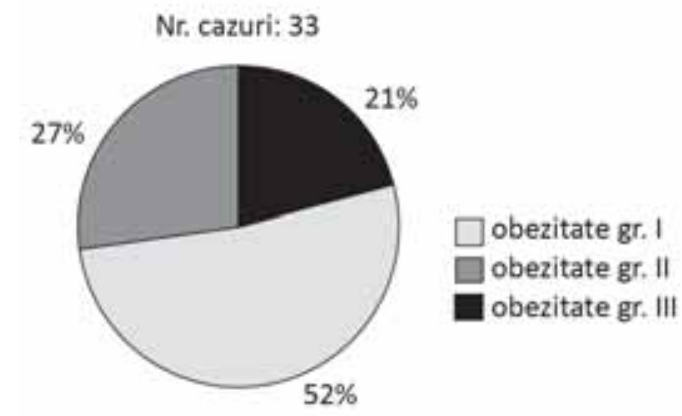

FIGURA 1. Repartiția lotului în funcție de gradul obezității

În majoritatea cazurilor, debutul creşterii ponderale excesive a avut loc la vârsta de 3 ani (49\%), urmată de perioada de sugar (30\%). Perioadele de câştig ponderal rapid au fost legate de: convalescența unor boli infecțioase - 3 cazuri $(9 \%)$, tratamente medicamentoase (Prednison) - 2 cazuri (6\%), sedentarism - 4 cazuri (12\%), hiperfagie şi obiceiuri alimentare vicioase -21 de cazuri (64\%). În 3 cazuri (9\%) nu s-a evidențiat nici un ,element vizibil““ din patogenia bolii.

Anamneza a evidențiat că 2 dintre pacienți au prezentat greutate la naştere $(\mathrm{GN})$ mică, iar 6 greutate mare (peste $4.000 \mathrm{~g}$ ). Datele din literatură confirmă faptul că GN peste 4.000 g este asociată cu un risc crescut de obezitate atât în copilărie, cât şi la vârsta de adult, în comparație cu bolnavii care au avut la naştere o greutate sub 4.000 g. În acelaşi timp, GN sub $2.500 \mathrm{~g}$ este asociată cu un risc scăzut de a dezvolta supraponderalitate față de persoanele cu GN peste $2.500 \mathrm{~g}(9-12)$.

Corelând greutatea cu talia, am observat că 21 de cazuri (64\%) prezentau o creştere mai accelerată atât a greutății, cât şi a taliei, creşterea ponderală depăşind proporțional creşterea în lungime. 12 cazuri $(36 \%)$ prezentau un exces de greutate raportat la o talie normală.

Creşterea alarmantă şi aparenta refractaritate a obezității copilului au impus evaluarea în vederea identificării factorilor care contribuie la excesul ponderal timpuriu, în mod particular în grupurile cu risc crescut, grup în care se încadrează şi preşcolarii (13). 
10 cazuri (30\%) au avut istoric familial de obezitate (Tabelul 1). În 5 dintre cele 10 familii în care era prezentă obezitatea, părinții prezentau şi alte afectiuni induse sau agravate de obezitate: cardiopatie ischemică (1 caz), HTA (2 cazuri), diabet zaharat tip II (1 caz), astm bronşic (1 caz).

TABELUL 1. Repartiția cazurilor în funcție de istoricul familial

\begin{tabular}{|l|l|c|c|}
\hline \multicolumn{2}{|l|}{ Istoric familial } & Număr cazuri & Procent (\%) \\
\hline Negativ & 23 & 70 \\
\hline \multirow{2}{*}{ Pozitiv } & Un părinte obez & 7 & 21 \\
\cline { 2 - 4 } & Ambii părinți obezi & 3 & 9 \\
\hline
\end{tabular}

Ancheta familială cu privire la concepția aparținătorilor în legătură cu cât şi cum trebuie să mănânce copiii a evidențiat excesul alimentar în 64\% dintre cazuri. În unele familii (15 cazuri - 45\%) copiii erau forțați să servească întreaga cantitate de alimente (,sindromul de farfurie goală“), acesta fiind un mijloc de presiune psihologică din partea părinților.

Analiza obiceiurilor alimentare a evidenţiat că în 27 familii (82\%) masa cea mai bogată caloric era cina, obişnuindu-se să se consume alimente concentrate, cu conținut bogat de glucide şi lipide (cartofi prăjiţi, făinoase, carne de porc, dulciuri concentrate, garnituri cu mare valoare calorică, maioneză).

Ancheta alimentară a arătat faptul că numai 3 din cei 33 de bolnavi incluşi în lot au primit alimentație naturală timp de aproximativ 4 luni, ceilalți primind alimentație mixtă sau artificială precoce. Se ştie că laptele matern, cel puțin în primele 4 luni de viață, reprezintă un factor de protecție în ceea ce priveşte apariţia obezității (16). De asemenea, s-a observat că un număr mare de cazuri $(60 \%)$ au primit diluții necorespunzătoare de lapte de vacă sau concentrații prea mari de lapte praf. În 14 cazuri $(42 \%)$ nu s-au respectat principiile de diversificare a alimentaţiei sugarului.

Istoricul bolii a scos în evidență faptul că doar în 5 cazuri (15\%) familia s-a mai prezentat anterior la medic şi li s-au făcut recomandări alimentare şi pentru exerciții fizice. Această atitudine terapeutică a eşuat în toate cazurile din cauza nerespectării de către părinți a recomandărilor primite.

Ancheta alimentară efectuată cu minuțiozitate a permis aprecierea frecvenței ingestiei alimentelor din principalele grupe. Astfel, s-a evidențiat o alimentație dezechilibrată cu un consum exagerat de: lactate (lapte, iaurt, brânzeturi, unt) - 7 cazuri (21\%), carne (de porc, vită, pasăre) - 15 cazuri $(45 \%)$, ouă -10 cazuri $(30 \%)$, fructe -5 cazuri
(15\%), pâine şi alte produse făinoase (biscuiți, macaroane, paste, orez) - 26 de cazuri (79\%), sucuri - 15 cazuri $(45 \%)$. În toate cazurile s-a evidențiat un raport excesiv de calorii al dietei, în mod prelungit, acest exces provenind în special din consumul glucidelor. Urmărind variațiile calorice de la o zi la alta, s-a observat în majoritatea cazurilor un aport caloric crescut aproape zilnic, iar urmărirea repartiției caloriilor pe mese a evidențiat că masa cea mai bogată caloric era cina.

Pentru a testa dezechilibrul caloric al dietei (între aportul şi consumul de energie), cât şi pentru a putea schimba comportamentul față de aport, evaluarea celor 33 de pacienți a conținut şi o apreciere a activităţii fizice pe parcursul a 24 de ore, astfel:

- numărul orelor de somn (media): ziua: 1 oră şi 30 de minute, noaptea: 10 ore

- modul în care este parcursă distanța de la domiciliu până la grădiniță: pe jos - 7 cazuri; cu mijloace de transport - 18 cazuri

- numărul de ore de activitate liberă (plimbare, joc)/zi: 1 oră -10 cazuri (30\%), 2 ore -7 cazuri (2\%), 3 ore -3 cazuri ( $9 \%)$

- numărul de ore petrecute, în medie, zilnic, în fața televizorului sau la calculator (jocuri): 3 ore.

Numai 5 bolnavi participau împreună cu familia la activități fizice în comun (alergări pe stadion, plimbări cu tricicleta/bicicleta sau cu role).

Tratamentul administrat celor 33 de cazuri cu obezitate a constat din regim dietetic care să acopere 1.200 calorii/zi corelat cu un program de activități fizice, psihoterapia părinţilor şi educaţia terapeutică acestora (oferirea de informații cu privire la compozitiia alimentelor, alimentele care trebuie consumate în cantități limitate, dar ținând cont şi de unele preferințe ale copilului, participarea la jocuri atractive în aer liber în care părinții să fie parteneri sau la mici competiții care le aduc satisfacții). La nivel individual, tratamentul țintit pe dietă şi activitate fizică s-a dovedit a avea cea mai mare rată de eficacitate, deoarece comportamentul la vârsta copilăriei este încă maleabil (20). În acelaşi timp, s-a observat ameliorarea stării generale a pacienților şi creşterea senzației de bunăstare a acestora.

\section{DISCUTุII}

Creşterea accelerată a taliei departajează obezitatea prin exces alimentar de obezitatea simptomatică din sindroame genetice şi endocrinopatii la care tabloul clinic se asociază cu semne/simptome specifice (dismorfii, retard). 
Debutul precoce al obezității este puternic corelat cu moştenirea ereditară şi resetările epigenetice sub influenţa unor factori din mediu ,in utero“ şi postnatal.

Creşterea la nivel global a prevalenței obezității şi supraponderii în rândul copiilor se datorează, pe de o parte, creşterii aportului energetic, în special de alimente cu densitate calorică crescută, bogate în grăsimi, zaharuri, iar pe de altă parte, scăderii activității fizice ca urmare a creşterii sedentarismului.

Rolul părinţilor în ceea ce priveşte excesul alimentar este esențial, mamele supraponderale având tendinţa să ofere copiilor porții mai mari şi cu un conținut mai mare de grăsimi (14).

Copiii sunt predispuşi să fie inactivi seara, după cină, în faţa televizorului sau calculatorului, în acest fel excesul de calorii nefiind consumat (15). În toate cazurile s-a evidențiat o alimentație dezechilibrată în principalele principii nutritive şi, de asemenea, în toate cazurile copiii consumau între mese suplimente calorice (dulciuri, băuturi răcoritoare).

Creşterea frecvenței alimentației artificiale (excesul de glucide şi încărcarea osmotică excesivă a formulelor de lapte), introducerea precoce a alimentelor solide (diversificarea precoce), folosirea pe scară tot mai largă de preparate comerciale în alimentaţia diversificată (majoritatea dezechilibrate, cu aport glucidic şi caloric crescut şi aport de proteine redus) au condus la o creştere excesivă în greutate a sugarilor şi tendinţa la depozitare excesivă de grăsime. Se ştie că factorii parentali, precum nivelul redus al cunoştințelor părinţilor, oferirea alimentelor dulci drept recompensă, lipsa timpului, insuficienta informare asupra unei alimentații sănătoase, joacă un rol important în influențarea dietei obezogene a copiilor mici (17).

Există studii care au sugerat existența unei corelații pozitive între consumul excesiv de alimente şi obezitatea la copii, chiar şi în cazul controlului altor factori precum exerciţiul fizic şi greutatea corporală a părinților (19).

În urma aprecierii activităţii fizice pe parcursul a 24 de ore, bolnavilor le-au fost redactate reco- mandări privind modificarea regimului de activitate fizică şi introducerea unor activități fizice suplimentare care să ducă la creşterea consumului energetic.

Introducerea exercițiilor fizice în rutina zilnică precum şi în cadrul curriculei preşcolarilor s-a dovedit a avea efecte benefice în reducerea incidenței obezităţii (21). Un rol important îl are şi implicarea familei, deoarece atitudinea, percepțiile şi comportamentul părinților pot influența dezvoltarea greutăţii corporale a copiilor (22).

\section{CONCLUZII}

Greutatea mare la naştere poate reprezenta un factor de risc pentru dezvoltarea obezităţii la vârsta preşcolară.

Obezitatea preşcolarilor din lotul studiat a fost de origine exogenă, prin hiperfagie, fiind implicate în acelaşi timp stilul de viaţă sedentar şi comportamentul alimentar vicios, cu un dezechilibru caloric important al dietei.

Pentru preşcolarii cu obezitate, foarte importantă este cooperarea familiei pentru realizarea unei alimentații adecvate şi menținerea unui stil de viaţă activ.

Accentul în combaterea obezității copilului trebuie deplasat spre profilaxia acesteia, deosebit de importante fiind măsurile pentru promovarea unei alimentaţii sănătoase şi pentru combaterea sedentarismului.

Profilaxia obezității presupune antrenarea tuturor releelor implicate în educaţia părinţilor şi copilului (medici, şcoală, mass-media) cu privire la alimetație şi stil de viaţă activ al copiilor, începând cu vârsta mică.

Tratamentul obeizității medii şi severe este dificil şi presupune o abordare multidimensională (educatori, nutriționişti, pediatri, psihologi, instructori-antrenori) pentru obținerea reducerii indicelui de masă corporală cu ,paşi mici“. 